\title{
Nitric Oxide Activates Signaling by c-Raf, MEK, p-JNK, p38 MAPK and p53 in Human Mesenchymal Stromal Cells and inhibits their Osteogenic Differentiation by Blocking Expression of Runx2
}

Tino Felka ${ }^{1}$, Christine Ulrich ${ }^{1}$, Bernd Rolauffs ${ }^{2}$, Falk Mittag ${ }^{3}$, Torsten Kluba ${ }^{3}$, Peter DeZwart ${ }^{2}$, Gunnar Ochs ${ }^{2}$, Michael Bonin ${ }^{4}$, Kay Nieselt $^{5}$, Melanie L Hart ${ }^{1,6}$, Kurt Geckeler ${ }^{7}$ and Wilhelm K Aicher ${ }^{1,6 *}$

${ }^{1}$ ZMF Center for Medical Research, University of Tuebingen Medical Faculty, Tuebingen, Germany ${ }^{2}$ Department of Trauma Surgery, University of Tuebingen, Tuebingen, Germany

${ }^{3}$ Department of Orthopaedic Surgery, University of Tuebingen Hospital, Tuebingen, Germany

${ }^{4}$ Institute of Medical Genetics and Applied Genomics, University of Tuebingen, Tuebingen, Germany

IIntegrative Transcriptomics, Center for Bioinformatics, University of Tuebingen, Tuebingen, Germany

${ }^{6}$ KFO273, Department of Urology, University of Tuebingen Hospital, Tuebingen, Germany

${ }^{7}$ School of Materials Science and Engineering, Gwangju Institute of Science \& Technology (GIST), 1 Oryong-dong, Buk-gu, Gwangju 500-712, South Korea

\begin{abstract}
Introduction: Mesenchymal stromal cells (MSC) are a promising therapy for wound healing and regeneration of inflamed tissues. They are used clinically for different symptoms and diseases and are being investigated in clinical trials world wide at an increasing rate. However, depending on the application protocol and site of treatment, MSC may face an inflammatory environment.
\end{abstract}

Objective: Nitric oxide (NO) is one of the soluble factors produced in acute and chronic inflammation and influences growth, apoptosis, proliferation and differentiation of cells. NO therefore my have an influence on MSC injected into inflamed sites. Thus we investigated the effects of NO radicals on human MSC.

Methods: Human MSC were expanded and characterized. Expression of the mesenchymal linage markers was determined by flow cytometry and their tri-lineage differentiation was explored in vitro. MSC were incubated with the NO-donor sodium nitroprusside (SNP) at different concentrations $(5 \mu \mathrm{M}-5 \mathrm{mM})$ and over different periods of time (15 min-24 hrs), and analyzed for their respiratory activity, gene expression responses, cell signalling pathways, and differentiation potential.

Results: Human MSC expressed the mesenchymal marker proteins CD73, CD90, CD105, CD146, but failed to express the hematopoietic markers CD11b, CD14, CD34, and CD45. Activation of the MSC in vitro by nitric oxide activated c-Raf-, p-38-MAPK, and p-JNK- mediated signalling in a dose dependent manner, and also significantly regulated genes involved in cellular proliferation (cyclin D1, GAS1), apoptotis (p53), and induced an intense nuclear factor E2-related factor (NRF2)-associated stress response. Moreover, NO inhibited the entry of MSC in the osteogenic differentiation pathway and NO-treated MSC expressed less of the transcription factor Runx2. In contrast, the expression of the adipogenic marker gene PPARY2 remained unchanged.

Conclusion: We conclude that NO modulates the metabolism of MSC and compromises their osteogenic differentiation potential, which may have detrimental consequences for bone remodelling or bone regeneration.

Keywords: Mesenchymal stromal cells; MSC; Nitric oxide; NO radicals; Cell differentiation; Osteogenesis; Runx2

\section{Introduction}

Mesenchymal stromal cells (MSC), also referred to as mesenchymal stem cells, are attracting interest for different applications, including tissue engineering and regenerative cell-based therapies [1,2]. They have been applied clinically to control autoimmune and graftversus-host diseases [3-6]. MSC are characterized by fibroblast-like morphology, high proliferation rate, attachment to cell culture dishes and the capacity to differentiate into different mesenchymal lineages [1]. MSC express a set of mesenchymal surface antigens such as CD73, CD90, CD105, and others, but lack expression of hematopoietic antigens CD14, CD34 and CD45 [7-9].

Possible clinical applications for MSC are wide ranging. They have been used to treat bone or chondral defects [10-15], facilitate muscular regeneration [16], modulate cancer development [17], vascularisation $[18,19]$, and deliver anti-inflammatory effects in vivo [20]. However, in clinical applications to support wound healing and regeneration of inflamed tissues, MSC may face pro-inflammatory stimuli such as interleukin-1 (IL1 $\beta$ ) or tumour necrosis factor- $\alpha$ (TNF $\alpha$ ), which influence their gene expression patterns $[21,22]$.

Nitric oxide (NO) is a free radical that is synthesized in acute and chronic inflammation [20,23-26]. It is produced in vivo by oxidation of L-arginine to L-citrulline. This reaction is catalyzed by different NO synthases (NOS). The endothelial (eNOS) and neuronale (nNOS) NO synthases are expressed constitutively and produce low amounts of NO

*Corresponding author: Prof. Dr. Wilhelm K. Aicher, KFO273, Department of Urology, University of Tuebingen Hospital (UKT), Paul-Ehrlich-Str. 15, 72076 Tuebingen, Germany, Tel: +49 7071298 7020; Fax: +49 7071292 5072; E-mail: aicher@uni-tuebingen.de

Received February 21, 2014; Accepted April 12, 2014; Published April 14, 2014

Citation: Felka T, Ulrich C, Rolauffs B, Mittag F, Kluba T, et al. (2014) Nitric Oxide Activates Signaling by c-Raf, MEK, p-JNK, p38 MAPK and p53 in Human Mesenchymal Stromal Cells and inhibits their Osteogenic Differentiation by Blocking Expression of Runx2. J Stem Cell Res Ther 4: 195. doi:10.4172/21577633.1000195

Copyright: (c) 2014 Felka T, et al. This is an open-access article distributed under the terms of the Creative Commons Attribution License, which permits unrestricted use, distribution, and reproduction in any medium, provided the original author and source are credited. 
Citation: Felka T, Ulrich C, Rolauffs B, Mittag F, Kluba T, et al. (2014) Nitric Oxide Activates Signaling by c-Raf, MEK, p-JNK, p38 MAPK and p53 in Human Mesenchymal Stromal Cells and inhibits their Osteogenic Differentiation by Blocking Expression of Runx2. J Stem Cell Res Ther 4: 195. doi:10.4172/2157-7633.1000195

[27]. Higher amounts are produced by the inducible NOS (iNOS) after stimulation of the cells by IL1 $\beta$, TNFa, or interferon- $\gamma$ (IFN $\gamma$ ) [28]. In MSC production of NO is elicited by activation of the cells by IFN $\gamma$ in the presence of either IL1 $\beta$ or TNF $\alpha$ [29]. In vitro, it has also been shown that activated macrophages produce up to $65 \mathrm{mM} / 10^{6}$ cells of intracellular NO within $72 \mathrm{hrs}$ [30], and this raise the extracellular nitrite concentrations to $80 \mathrm{mM}$ [31]. In the inflamed colon, $\mathrm{NO}$ production rates of $2.3 \pm 0.6 \mathrm{pmol} / \mathrm{sec}$ were calculated from $10^{6}$ cells, resulting in a cumulative dose of $560 \mu \mathrm{M} / \mathrm{min}$ to nearby cells [25]. Cytokine-activated macrophages began to undergo apoptosis when NO concentrations exceeded $115 \mathrm{mM}$ [32]. Hence, NO production at these concentrations or above is cytotoxic.

The small NO molecule can move freely across cell membranes, is quite stable under physiological conditions, and has a half-live time of approximately 2-3 sec. Therefore, within seconds NO may reach distances of $200 \mu \mathrm{m}$ in tissues [33]. Depending on the concentration and localization, $\mathrm{NO}$ is involved in numerous physiological processes [27]. At low concentrations $(<1 \mu \mathrm{M}) \mathrm{NO}$ affects different transcription factors. It also affects heme-containing enzymes such as guanylate cyclase [34]. Higher NO concentrations $(>1 \mu \mathrm{M})$ result in chemical reactions that modify proteins by nitrosylation or nitration [34]. Recent work suggests that physiological concentrations of NO may be in the pico- to nano-molar range, rather than in the micro-molar range [35]. This is a hundred fold below the concentration range considered physiological a few years ago [34]. Technical differences in either quantifying $\mathrm{NO}$ in vivo and in vitro or differences in delivering defined amounts of NO may account for the different concentrations reported in different experiments. But there is ample evidence that NO influences growth, apoptosis, proliferation and differentiation of different cell types, and may even promote tumorigenesis [13,3641]. Lack of cardiac NO production during embryonic development delayed the maturation of the heart. The affected mice ( eNOS $^{-/-}$) often died soon after birth [42], suggesting an important role for NO in proliferation and differentiation of mesenchymal progenitor cells.

Activation of iNOS and elevated production of NO are observed in chronic degenerative processes [23], acute injury [43,44], and inflammation $[20,24,45]$. Thus, NO radicals may represent a serious burden for transplantation of MSC in inflamed areas. Herein we report effects of $\mathrm{NO}$ on respiratory activity, gene expression and differentiation of human MSC.

\section{Materials and Methods}

\section{Isolation of human MSC}

Human MSC were isolated using Ficoll density gradient fractionation from femoral bone marrow aspirates of 11 patients undergoing endoprosthetic surgery as described [46]. This study was approved by the local ethics committee. MSC were expanded in lowglucose DMEM (Lonza) supplemented with $5 \%$ human fresh frozen plasma (FFP), $5 \%$ platelet concentrate $\left(10^{8}\right.$ platelets $/ \mathrm{ml}$ medium $)$, $2 \mathrm{mM}$ glutamine (Lonza), $1000 \mathrm{IU}$ heparin sodium (Roth), $100 \mathrm{U} /$ $\mathrm{ml}$ penicillin, $100 \mu \mathrm{g} / \mathrm{ml}$ streptomycin (Invitrogen). The starvation expansion medium utilized in several sets of experiments consisted of low-glucose DMEM suplemented with $0.5 \%$ FFP and $0.5 \%$ platelet concentrate.

\section{Characterization of human MSC}

The MSC were characterized according to the defined minimal criteria as described recently [7]. The expression of CD146, CD90,
CD11b (R\&D Systems), CD105, CD73, CD45, CD34, and CD14 (BD Pharmingen) was analysed by flow cytometry [47]. The differentiation to osteogenic or adipogenic cells was performed as described recently, visualized by cytochemical staining [47], and confirmed by quantification of transcripts encoding the corresponding marker genes (see below).

\section{XTT-assay}

To analyse the effect of NO radicals on MSC, cells were treated with NO-donor sodium nitroprusside (SNP, Calbiochem) at different concentrations ( $5 \mu \mathrm{M}$ to $5 \mathrm{mM}$ ). Under physiological conditions SNP breaks down by hydrolysis with a half-live time of approx. $10 \mathrm{~min}$. and causes e.g., relaxation of smooth muscle cells and vasodilatation cyclin $[48,49]$. Mock-treated cells served as controls. After $24 \mathrm{hrs}$ of incubation, the respiratory activity and viability of MSC were measured using a XTT- assay (EZ4U, Biomedica) according to the manufacturer's instructions. In this assay the water soluble dye (XTT) is reduced by mitochondrial dehydrogenases and NADH or NADPH to an insoluble formazan, which is detected by spectrophotometry. This assay therefore detects mitochondrial glycolysis (= respiratory activity) and NADH/NADPH content in viable cells. The data is expressed as normalized respiratory activity, and generation of formazan by mocktreated cells is set to a respiratory activity of $100 \% .(=1)$.

\section{Compensation of NO activity}

To investigate the specificity of NO-mediated effects, the reactive oxygen species were neutralized by addition of the water soluble fulleren PNIPAM-6C ${ }_{60}$ as described before [50]. In brief, The MSC was incubated in the presence of $1 \mu \mathrm{M}$ to $100 \mu \mathrm{M}$ PNIPAM-6C 60 and SNP was added ad $1.5 \mathrm{mM}$. Mock-treated cells (control 1) and cell incubated with $1.5 \mathrm{mM}$ SNP w/o PNIPAM-6C 60 (control 2) served as controls. After 24 hrs of incubation, metabolic activity / viability of the MSC was determined by XTT assay.

\section{Nitrite-nitrate assay}

Nitrite concentration was measured in cell culture media (control) or supernatants of mock-treated and SNP-treated MSC ( $5 \mu \mathrm{M}$ to $5 \mathrm{mM})$ utilizing a colorimetric nitrite-nitrate assay kit (Cayman Chemical) according to the manufacturer's protocol.

\section{Microarray analysis}

Sodium nitroprusside (add $1.5 \mathrm{mM}$ ) was added to MSC ( $\mathrm{n}=3$ donors) and the cells were incubated in starvation expansion medium for $24 \mathrm{hrs}$. MSC without SNP served as controls. Total RNA was isolated using the RN easy Kit (Qiagen) according to the manufacturer's protocol. The quality of the RNA was confirmed by chromatography and cRNA was produced. Gene expression analysis was performed by Affymetrix GeneChip ${ }^{\circledR}$ technology (Human U133+2.0 Genome). The gene expression data (Expression Console ${ }^{\circledR}$, Affymetrix) was evaluated by GeneSpring GX 11.5 software (Agilent Technologies).

\section{Transcript analysis}

To corroborate the NO-induced differences in expression of some representative genes in MSC, a quantitative RT-PCR (qRTPCR) analysis was performed. SNP (add $1.5 \mathrm{mM}$ ) was added to MSC ( $\mathrm{n} \leq 8$ donors) and the cells were incubated for $24 \mathrm{hrs}$ as described above. MSC without SNP served as controls. Total RNA was isolated, reverse transcription was performed on $1 \mu \mathrm{g}$ total RNA using the Advantage RT for PCR Kit (Clontech) to generate cDNA. Transcripts 
Citation: Felka T, Ulrich C, Rolauffs B, Mittag F, Kluba T, et al. (2014) Nitric Oxide Activates Signaling by c-Raf, MEK, p-JNK, p38 MAPK and p53 in Human Mesenchymal Stromal Cells and inhibits their Osteogenic Differentiation by Blocking Expression of Runx2. J Stem Cell Res Ther 4: 195. doi:10.4172/2157-7633.1000195

Page 3 of 9

were enumerated by qRT-PCR (LightCycler, Roche) [51] using commercially available primer pairs for sequestosome 1 (SQSTM1), peroxiredoxin 1 (PRDX1) glutathione reductase (GSR), thioredoxin reductase 1 (TXNRD1), ATP-binding cassette transporter (ABCC1), $\mathrm{NAD}(\mathrm{P}) \mathrm{H}$ dehydrogenase (NQO1), glutamate cysteine ligase (GCLM), aldehyde oxidase (AOX1), stress induced phosphoprotein 1 (STIP1), protein tyrosine phosphatase (PTPLAD1), ER stress induced domain 1 (HERPUD), valosin containing protein (VCP), tRNA guanine transglycosylase (USP 14) and FOS-like antigen 1 (FOSL1) (all from Qiagen). Serial dilutions of recombinant DNA standards served as controls. GAPDH served as the reference gene in each PCR [51].

To investigate the effects of NO on differentiation of MSC in vitro, expression of the osteogenic differentiation markers runt related transcription factor 2 (Runx2), and osteocalcin, and the adipogenic marker peroxisome proliferator-activated receptor gamma-2 (PPAR $\gamma 2)$ (all from QIAGEN) was determined. Serial dilutions of recombinant DNA standards served as controls. GAPDH served as the reference gene in each PCR [51].

\section{Immunoblot analysis}

For immunoblot analysis, $1 \times 10^{6}$ MSC were incubated with 10 $\mu \mathrm{M}$ or $1.5 \mathrm{mM}$ SNP for different periods of time (15 min to $24 \mathrm{~h}$ ). After washing with cold PBS, cells were harvested by mechanical detachment, collected by centrifugation and lysed in $100 \mu \mathrm{l}$ RIPA buffer (c-c-pro) containing proteinase inhibitors. The protein concentration was measured using the RCDC Kit (BioRad). Cellular protein extracts $(100 \mu \mathrm{g})$ were mixed with Laemmli sample buffer, denatured at $95^{\circ} \mathrm{C}$ and separated by electrophoresis in a $10 \%$ SDS-PAGE. After blotting, the nitrocellulose membrane was blocked with $5 \%$ milk, PBS, $0.1 \%$ Tween-20 (blocking buffer) and probed overnight at $4^{\circ} \mathrm{C}$ with $\mathrm{mAb}$ specific for phospho-c-Raf, phospho-MEK1/2, phosphoErk1/2 (Thr202/Tyr204), phospho-JNK (Thr183/Tyr185), phospho PI3K, phospho-p38, phospho-p53 (Ser15) and $\beta$-actin (Cell Signaling Technology). Secondary HRP-labelled goat-anti-rabbit-antibody (Jackson Immunoresearch) was used in blocking buffer. Binding of antibodies was visualized by enhanced chemiluminescence (ECL), by exposure of the luminiscence on Amersham Hyperfilm ${ }^{\text {TM }}$ ECL (GE Healthcare) and, then the film was developed in a photo developer (Curix 60, AGFA).

\section{Statistics}

Unless otherwise noted, experimental data are presented as mean values \pm standard deviations. Statistical analyses were performed using a two-sided Student's t-test. Differences in gene expression levels yielding $p$-values less than 0.05 were considered significant and marked accordingly $\left({ }^{*} \mathrm{p}<0.05,{ }^{* *} \mathrm{p}>0.01,{ }^{* *} \mathrm{p}<0.001\right)$.

\section{Results}

\section{Characterization of MSC}

The MSC were expanded and characterized as fibroblast-like cells that expressed the typical antigens CD73, CD90, CD105 and CD146. At the same time the expression of hematopoietic antigens CD11b, CD14, CD45 and CD34 was low or absent (Figure 1A). The MSC were able to differentiate to chondrogenic cells as visualized by Alcian Blue staining of proteoglycans in micro masses, to adipocytes as documented by Oil Red O staining of lipid vesicles, and to osteoblasts as documented by von Kossa staining of mineralized extracellular matrix (Figure 1B). Thus the cells employed in this study fulfilled the inclusion criteria defined for human bone marrow-derived MSC [7]

\section{Effect of NO radicals on respiratory activity of MSC}

The treatment of MSC $(n=3)$ with different concentrations of SNP revealed a dose dependent effect on MSC. Low SNP concentrations (10-25 $\mu \mathrm{M})$ yielded a slight increase in the respiratory activity of MSC (up to $120 \%$ ) compared to untreated controls (100\%) as depicted by the XTT assay. Higher SNP doses (1 mM and higher) resulted in a decrease in the respiratory activity of MSC (60\%-20\%, Figure $2 \mathrm{~A})$. As shown in our recent study with cell lines [50], addition of the fullerene-based water soluble radical scavenger PNIPAM-6C 6 rescued the respiratory activity on NO-treated human MSC (Figure $2 \mathrm{~B}$ ). This confirmed that the effects observed were caused by NO-radicals.
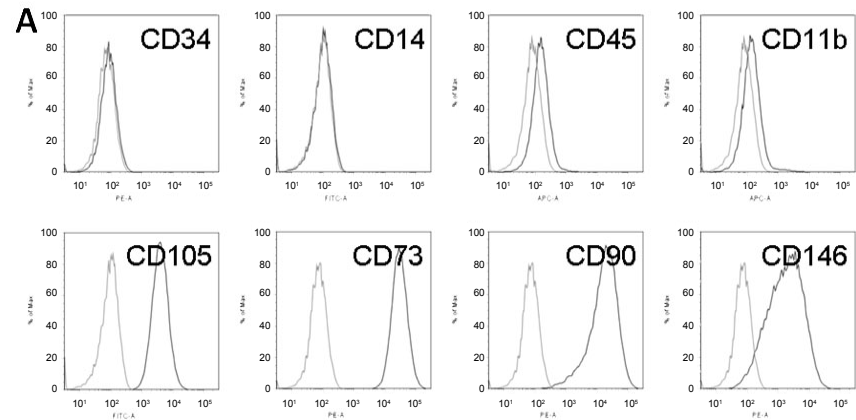

B

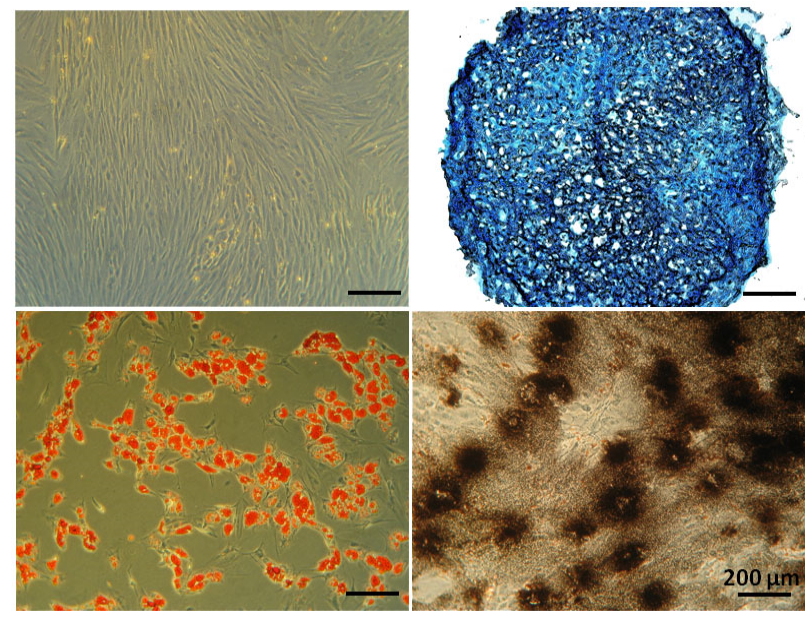

Figure 1: Characterization of MSC

A. Expression of cells surface proteins on human MSC was investigated by flow cytometry [7]. Expression of CD34, the marker for hematopoietic stem and progenitor cells, CD14, the co-receptor for LPS on macrophages, CD45 the common leucocyte antigen, and CD11b, the complement receptor 3 (= Mac-1, ITGAM) were not detected or showed very low expression on MSC in vitro. MSC expressed the typical antigens including TGF- $ß$ receptor CD105 (endoglin), CD73 (5'ecto-nuclease), CD90 (GPI-anchored glycoprotein, = Thy1), and CD146 (adhesion molecule, = MUC18, MCAM).

B. The tri-lineage differentiation of MSC was investigated after 4 weeks of differentiation in vitro. Chondrogenesis was induced in micromasses and differentiation was documented by Alcian Blue staining (upper right). Adipogenesis (lower left) and osteogenesis (lower right) were induced in monolayer cultures and success of differentiation was investigated by Oil Red $\mathrm{O}$ and von Kossa staining, respectively. MSC in expansion medium maintained their fibroblastoid appearance and served as controls (upper left). Size bars measure $200 \mu \mathrm{m}$. 
Citation: Felka T, Ulrich C, Rolauffs B, Mittag F, Kluba T, et al. (2014) Nitric Oxide Activates Signaling by c-Raf, MEK, p-JNK, p38 MAPK and p53 in Human Mesenchymal Stromal Cells and inhibits their Osteogenic Differentiation by Blocking Expression of Runx2. J Stem Cell Res Ther 4: 195. doi:10.4172/2157-7633.1000195

Page 4 of 9
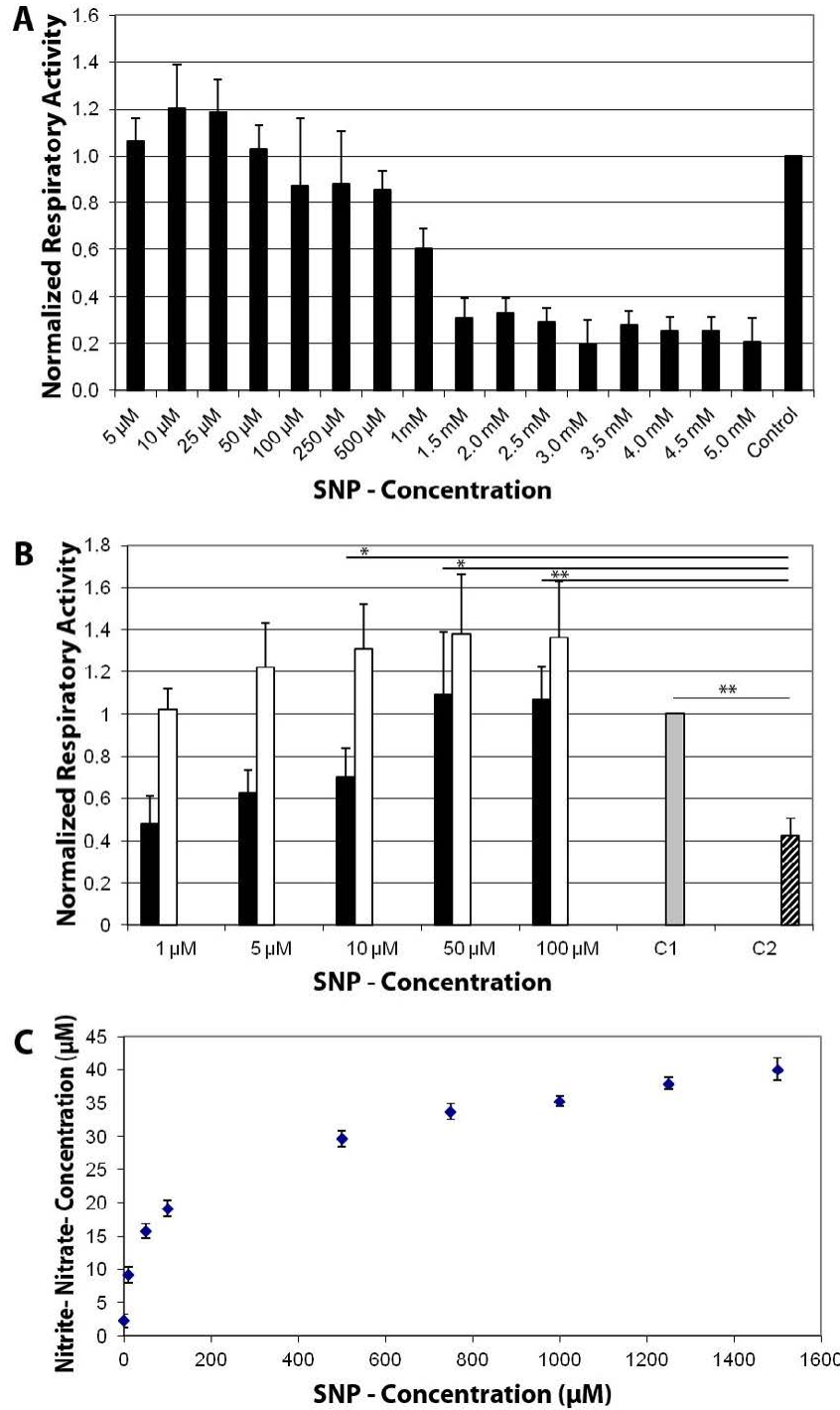

Figure 2: Effects of nitric oxide radicals on cell viability and nitrite-nitrate formation in cell culture media.

A SNP was added to MSC in concentrations ranging from $5 \mu \mathrm{M}$ to $5 \mathrm{mM}$ and respiratory activity was measured by XTT assay. Low doses of SNP $(10 \mu \mathrm{M}$ and $25 \mu \mathrm{M}$ ) activated respiratory activity to some extent. SNP at $100-500 \mu \mathrm{M}$ reduced the respiratory activity of MSC to approximately $80 \%$. Dosages of 1 mM SNP or higher reduced the respiratory activity of MSC to $30 \%$ or $20 \%$. Mock-treated MSC served as controls (= 100\%).

B Human MSC was incubated for $24 \mathrm{~h}$ in medium without SNP (C1, striated column) or in presence of $1.5 \mathrm{mM}$ SNP (C2, grey column). Addition of SNP reduced the normalized respiratory activity / viability of MSC to $42 \%$ compared to the mock-treated controls $(=100 \%)$. Addition of $1 \mu \mathrm{M}$ and $5 \mu \mathrm{M}$ PNIPAM$6 \mathrm{C}$ elevated measurably but statistically not significant to $47 \%$ and $62 \%$, respectively. Addition of $10 \mu \mathrm{M}, 50 \mu \mathrm{M}$, or $100 \mu \mathrm{M}$ PNIPAM-6C $\mathrm{C}_{60}$ elevated the respiratory activity / viability of SNP-treated human MSC significantly to $70 \%$ ( $\pm 13 \%$; $p<0.039), 101$ ( $\pm 29 \%$; $<<0.02)$, and 101 ( $\pm 16 \%, p<0.004$; black bars) Addition of PNIPAM- $6 \mathrm{C}_{60}$ only did not reduce the respiratory activity / viability of human MSC (white bars).

C The formation of nitrite / nitrate in MSC cultures was investigated following addition of SNP at concentrations between $5 \mu \mathrm{M}$ and $1.5 \mathrm{mM}$ and determined after $24 \mathrm{~h}$ of incubation. At lower SNP concentrations (up to $500 \mu \mathrm{M}$ ) a steep increase in nitrite / nitrate concentrations $(0-35 \mu \mathrm{M})$ was measured. Higher SNP concentrations $(500$ to $1500 \mu \mathrm{M})$ resulted in a slight increase of nitrite / nitrate concentration ( 35 to $40 \mu \mathrm{M}$ ).

\section{Nitrite accumulation}

S-nitrosylation by $\mathrm{NO}$ is a mechanism for post-translational modification of many proteins. However, at high concentrations of NO, nitrosylation may yield toxic effects and nitrite will accumulate. The accumulation of nitrite after 24 hrs of incubation of MSC (n=3) with different concentrations of SNP was measured by the nitritenitrate assay (Figure 2C). Incubation of MSC in medium containing 10 $\mu \mathrm{M}$ SNP resulted in a nitrite concentration of $9.2 \mu \mathrm{M}( \pm 1.2 \mu \mathrm{M})$ in the supernatants. A steep increase in nitrite concentration was observed at low doses of SNP. Addition of $500 \mu \mathrm{M}$ SNP or more yielded smaller increases in nitrite concentrations. Concentrations of $500 \mu \mathrm{M}$ SNP to $1.5 \mathrm{mM}$ SNP resulted in a significant drop of respiratory activity of MSC (Figure 2A) and in this range of SNP dosages an accumulation of $29( \pm 1.5) \mathrm{mM}$ to $40 \mu \mathrm{M}( \pm 1.7 \mu \mathrm{M})$ nitrite (Figure $2 \mathrm{C})$. Thus, the mitogenic effects measured with low SNP concentrations on MSC in vitro were possibly associated with $\mathrm{NO}$ activity itself, whereas toxic effects observed upon addition of SNP at concentrations of $500 \mu \mathrm{M}$ or more may be caused mainly by nitrite.

\section{Effect of SNP on gene expression of MSC}

The incubation of MSC with SNP (1.5 mM, $24 \mathrm{hrs)} \mathrm{yielded} \mathrm{for}$ instance a significant elevation of transcripts encoding cyclin D1 (5.6-fold up, $\mathrm{p}<0.02$ ) and growth arrest-specific 1 gene (GAS1, 10.9fold down, $\mathrm{p}<0.01$ ) was significantly reduced. Thus, depending on the conditions, NO may facilitate the G1/S transition of the cell cycle in MSC. Significant changes in mRNA expression patterns (factor $\geq 2$ ) of more than 1000 genes were observed (gene array data not shown). These genes were compared to known regulatory networks and pathways and related to cellular and physiological functions, as well as diseases. A high number of NO-regulated factors were associated with regulation of proliferation, growth and cell death (Table 1). A comparison to known regulatory networks and pathways indicated a connection to tumorigenic processes as well. By gene array, the most significant changes were observed for the NRF2-mediated oxidative stress response pathway ( $\mathrm{p}=4.73 \mathrm{E}-06$; Table 1$)$. In this canonical pathway NO significantly induced for instance the expression of the modifier subunit of glutamate-cystein ligase (GCLM, 5.4-fold up, $\mathrm{p}<0.004)$

\begin{tabular}{|l|l|l|}
\hline Molecular and Cellular Functions & p-value & \# Genes \\
\hline Growth, Proliferation & $8.47 \mathrm{E}-05-1.81 \mathrm{E}-02$ & 172 \\
\hline Cell Death & $4.76 \mathrm{E}-06-2.04 \mathrm{E}-02$ & 253 \\
\hline Small Molecule Biochemistry & $1.89 \mathrm{E}-05-1.89 \mathrm{E}-02$ & 104 \\
\hline Amino Acid Metabolism & $1.89 \mathrm{E}-05-1.43 \mathrm{E}-02$ & 17 \\
\hline Lipid Metabolism & $2.72 \mathrm{E}-05-1.89 \mathrm{E}-02$ & 79 \\
\hline Diseases & & \\
\hline Cancer & $6.52 \mathrm{E}-14-2.22 \mathrm{E}-02$ & 448 \\
\hline Reproductive System Disease & $3.10 \mathrm{E}-05-1.86 \mathrm{E}-02$ & 151 \\
\hline Gastrointestinal Disease & $1.47 \mathrm{E}-06-2.10 \mathrm{E}-02$ & 126 \\
\hline Top Canonical Pathways & & \\
\hline NRF2-mediated oxidative stress response & $1.65 \mathrm{E}-06$ & 23 \\
\hline Pyrimidine Metabolism & $5.35 \mathrm{E}-03$ & \\
\hline Interferon Signaling & $6.18 \mathrm{E}-03$ & \\
\hline Glutathione Metabolism & $5.02 \mathrm{E}-03$ & \\
\hline
\end{tabular}

List of the most significantly regulated pathways modulated by NO in MSC. The molecular and cellular functions of the annotated pathways are listed in the left column, the levels of significances (i.e., p-value) for changes in NO-dependent gene regulation in the respective pathways in the middle, and numbers of factors or genes regulated by NO in the right column (1.5 mM SNP, $24 \mathrm{hrs}$ )

Table 1: Significant NO-regulated pathways in human MSC: a brief summary of microarray data. 
Citation: Felka T, Ulrich C, Rolauffs B, Mittag F, Kluba T, et al. (2014) Nitric Oxide Activates Signaling by c-Raf, MEK, p-JNK, p38 MAPK and p53 in Human Mesenchymal Stromal Cells and inhibits their Osteogenic Differentiation by Blocking Expression of Runx2. J Stem Cell Res Ther 4: 195. doi:10.4172/2157-7633.1000195

Page 5 of 9

\begin{tabular}{|c|c|c|c|c|}
\hline \multirow{3}{*}{$\begin{array}{l}\text { Method: } \\
\text { SNP Dosage: } \\
\text { Genes: }\end{array}$} & \multicolumn{3}{|c|}{ Differences mRNA expression } & \multirow[t]{3}{*}{ Function } \\
\hline & \multirow{2}{*}{$\begin{array}{c}\text { Array } \\
1.5 \mathrm{mM}\end{array}$} & \multicolumn{2}{|c|}{ qRT-PCR } & \\
\hline & & $1.5 \mathrm{mM}$ & $10 \mu \mathrm{M}$ & \\
\hline $\begin{array}{l}\text { Sequestosome } 1 \\
\text { Peroxiredoxin } 1 \\
\text { Gluthathionereductase } \\
\text { Thioredoxinreductase } 1\end{array}$ & $\begin{array}{c}11.58 \\
2.47 \\
3.37 \\
4.2\end{array}$ & $\begin{array}{c}2.3 \\
3.87 \\
3.31 \\
6.1\end{array}$ & $\begin{array}{r}-1.85 \\
-1.06 \\
1.96\end{array}$ & $\begin{array}{l}\text { Antioxidative } \\
\text { protein }\end{array}$ \\
\hline ATP binding cassette transporter & 3.28 & 1.35 & 1.02 & Drug resistance \\
\hline $\begin{array}{l}\mathrm{NAD}(\mathrm{P}) \mathrm{H} \text { - dehydrogenase } \\
\text { Glutamate cysteine ligase } \\
\text { Aldehyde oxidase }\end{array}$ & $\begin{array}{r}5.38 \\
-2.44\end{array}$ & $\begin{array}{r}5.66 \\
6.84 \\
-3.13\end{array}$ & $\begin{array}{c}-1.37 \\
-1.72 \\
-2\end{array}$ & $\begin{array}{l}\text { De-toxification, } \\
\text { cell survival- tumorgenesis }\end{array}$ \\
\hline $\begin{array}{l}\text { Stress induced phosphoprotein } 1 \text { Protein tyrosine phosphatase } \\
\text { ER stress induced domain } 1 \\
\text { Valosin containing protein } \\
\text { tRNA guanine transglycosylase }\end{array}$ & $\begin{array}{l}2.52 \\
2.05 \\
2.09\end{array}$ & $\begin{array}{c}-1.45 \\
-1.43 \\
1.07 \\
1.61\end{array}$ & $\begin{array}{c}-2.63 \\
-2.63 \\
2.17 \\
-1.35\end{array}$ & Repair and removal of damaged proteins \\
\hline FOS like antigen 1 & 11.27 & 6.92 & 1.22 & Modulation of malignant cells \\
\hline
\end{tabular}

Selected factors regulated by NO in human MSC in comparison to untreated cells showed x-fold differences dependent on the concentration of SNP added. Data were selected from the transcript array data or computed from qRT-PCR as indicated. Factors expressed at higher steady state mRNA levels upon incubation of MSC with SNP are denoted in italics, and factors expressed at lower levels in bold numbers

Table 2: NO-regulated relative mRNA expression of stress response genes in MSC

and the microsomal glutathion S-transferase 1(MGST1, 3.74-fold up, $\mathrm{p}<0.015)$. The other NO-regulated canonical pathways significantly changed included the pyrimidine metabolic pathway ( $\mathrm{p}=5.35 \mathrm{E}-03$ ), interferon signalling $(\mathrm{p}=6.18 \mathrm{E}-03)$ and glutathione metabolic pathway $(\mathrm{p}=7.91 \mathrm{E}-03)$. The results indicated that NO provoked a significant change in the metabolism of human MSC.

\section{Analysis of the nuclear factor E2-related factor (NRF2)- mediated oxidative stress response pathway}

Factors associated with the NRF2-mediated oxidative stress response were the most significantly altered pathways upon $\mathrm{NO}$ stimulation of MSC (Table 1). To validate these gene array experiments, qRT-PCR analyses were performed for some representative genes and the differences induced by high concentrations of NO (1.5 mM SNP) were enumerated in independent samples (Table 2). At the same time, the effects of low concentration of NO were tested (10 $\mu$ M SNP; Table $2)$. High SNP concentration $(1.5 \mathrm{mM})$ yielded an increase in gene expression encoding proteins associated with anti-oxidation (e.g., sequestosome 1, peroxiredoxin 1), drug resistance (e.g., ATP binding cassette transporter), detoxification, cell survival and tumorigenesis (e.g., $\mathrm{NAD}(\mathrm{P}) \mathrm{H}$-dehydrogenase, glutamate cystein ligase, aldehyde oxidase), as well as repair and removal of damaged proteins (Table 2). However, low concentrations of SNP $(10 \mu \mathrm{M})$ yielded either a slight increase or a decrease of mRNA expression of stress response genes as detected on the transcript levels by qRT-PCR.

The NRF2-mediated pathway includes activation of different mitogen activated protein kinases (MAP-kinases) [52], followed by changes of mRNA expression of stress response genes. Therefore the activation of MAP-kinases after incubation of MSC with SNP at a low dose $(10 \mu \mathrm{M})$ and a high dose $(1.5 \mathrm{mM})$ was investigated by analysis of the phosphorylation kinetics for up to $24 \mathrm{hrs}$ after stimulation (Figure 3). At low dose SNP treatment, changes in phosphorylation of MEK1/2, ERK-1/2 p38, JNK or p53 were not observed, but a transiently enhanced phosphorylation of c-Raf was recorded thirty minutes to two hours after stimulation (Figure 3). At high dosage, SNP yielded the transient phosphorylation of c-Raf as observed with $10 \mathrm{mM}$ SNP. In addition, $1.5 \mathrm{mM}$ SNP resulted in a significant phosphorylation signal for MEK-1/2 and JNK eight and twelve hours after stimulation, and for p38 an increase in phosphorylation signal intensities was seen one to twelve hours after induction (Figure 3). Furthermore, addition of $1.5 \mathrm{mM}$ SNP caused a phosporylation of serine at position 15 of the apoptosis regulating factor p53. Phosporylation of p53 was not observed with $10 \mathrm{mM}$ SNP (Figure 3), confirming the pro-apoptotic effects of higher concentrations of NO on MSC (Figure 2A).

\section{Effect of NO on osteogenic differentiation of MSC}

Regeneration of bone fractures and wound healing after bone surgery require osteogenic differentiation of MSC. Stimulation of MSC by NO caused an activation of c-Raf (Figure 3). Parathyroid hormone $(\mathrm{PTH})$ is involved in regulation of both, growth and apoptosis of osteoblasts by an intracellular signaling cascade involving MAP kinases and c-Raf [53]. We therefore investigated the effects of NO on the osteogenic differentiation of MSC in vitro (Figure 4). Incubation of MSC for 7 days in osteogenic differentiation media in the absence of SNP elevated the expression of transcription factor Runx2, an early key regulator of osteogenic differentiation [54] (Figure 4A). Addition of SNP to cells in osteogenic differentiation medium (medium enriched by $1 \mathrm{mM}$ SNP changed daily for 7 days) completely blocked the elevated expression of Runx2 transcripts (Figure 4A), suggesting that $\mathrm{NO}$ affected the early stages of osteogenic differentiation. In contrast, induction of osteocalcin expression, a late marker of osteogenesis, was only slightly elevated (Figure 4B), suggesting that within this short period of induction time (i.e., 7 days) only entry in osteogenic differentiation was achieved.

In addition, induction of adipogenic differentiation was investigated, and PPAR $\gamma 2$, a marker gene for adipogenic differentiation of MSC, was significantly elevated after 7 days of induction (Figure 4C). But in contrast to the effects of $\mathrm{NO}$ on Runx2 expression (Figure 4A), a reduction of expression of PPAR $\gamma 2$ was not observed in MSC during adipogenesis in the presence of SNP (Figure 4C). We conclude that excess $\mathrm{NO}$, as produced in chronic inflammatory processes, alleviates osteogenic differentiation of MSC and thus may contribute to reduced fracture healing and bone regeneration in vivo. Through blocking osteogenesis in MSC, NO may also facilitate osteoporosis, a condition affecting the elderly, whereas low NO concentrations may be beneficial, as this may stimulate proliferation of MSC in situ.

\section{Discussion}

The treatment of MSC with the NO donor SNP at low 
Citation: Felka T, Ulrich C, Rolauffs B, Mittag F, Kluba T, et al. (2014) Nitric Oxide Activates Signaling by c-Raf, MEK, p-JNK, p38 MAPK and p53 in Human Mesenchymal Stromal Cells and inhibits their Osteogenic Differentiation by Blocking Expression of Runx2. J Stem Cell Res Ther 4: 195. doi:10.4172/2157-7633.1000195

Page 6 of 9

$10 \mu \mathrm{M} \mathrm{SNP}$

Time course (h)

$\begin{array}{llllllllll}0 & 0.25 & 0.5 & 1 & 2 & 4 & 8 & 12 & 24\end{array}$

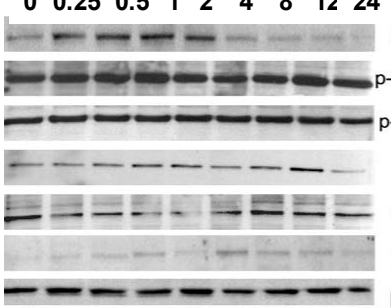

Figure 3: Phosphorylation kinetics of MAP-Kinases after incubation of MSC with SNP.

MSC were activated by addition of $10 \mu \mathrm{M}$ (left panel) and $1.5 \mathrm{mM}$ SNP (right panel) for different lengths of time as indicated, and phosphorylation of intracellular signaling proteins was recorded. A transient phosphorylation of c-RAF was observed by low and high dosages of SNP. MEK1/2 and ERK1/2 were found in a phosphorylated stage even prior to stimulation $(t=0)$, whereas JNK and p53 proteins were not. Addition of $1.5 \mathrm{mM}$ SNP resulted in a substantial phosphorylation signal for MEK-1/2 and JNK eight and twelve hours after stimulation. Low SNP failed to do so. The p53 protein was modified by phosphorylation of serine at position 15 after addition of $1.5 \mathrm{mM} \mathrm{SNP}$, but not by $10 \mu \mathrm{M}$ SNP. Reprobing of the membrane with anti- $\beta$-actin served as the loading control.

concentrations did not significantly affect the metabolic activity of MSC. The normalized respiratory activity and viability index was about $20 \%$ above the mock-treated controls. This slight increase in metabolic activity could be associated with the cell signalling effects reported for cytoplasmic NO. Nitric oxide binds to the heme moiety of soluble guanylate cyclase (sGC), triggering its enzymatic activity within seconds, and generates cGMP [55]. The various cGMP regulated signalling pathways include kinases, cGMP-gated ion channels, and phosphodiesterases. Moreover, activation of sGC inhibits apoptosis [56], which may cause the trend towards higher metabolic activity or cellular viability. A significant induction of D1 (5.6-fold up, $\mathrm{p}<0.02)$ and a more that tenfold reduction of GAS1 $(10.9$-fold down, $\mathrm{p}<0.01)$ by SNP were noted, thus facilitating cell cycle progression [57]. The activation of $\mathrm{c}$-Raf by low doses of NO may contribute to proliferative activation of MSC as well [58].

Addition of SNP to MSC at higher concentrations $(100 \mu \mathrm{M}$ to 1.5 $\mathrm{mM}$ ) resulted in a concentration-dependent reduction of the respiratory activity of MSC. Needless to say that addition of SNP to cells in these concentrations does not deliver NO in comparable amounts over an extended time. In cell culture media containing serum, SNP has a halflife of about 30 minutes, and after 2 hours of incubation more than $90 \%$ of its activity is lost [59]. Therefore, the effective concentrations of NO in these experiments are considerably lower than one might assume from initial SNP input. However, specific measurement of NO in supernatants of cell culture media used for growth of somatic cells is a complex endeavour. A recent study publishing a spectrophotometric method to measure NO omitted glutamine, serum and phenol red in the cell culture medium [60]. Therefore this technique is not suitable as NO release from SNP may be different in medium containing glutamine, serum and phenol red. Others used chemiluminescence to detect reactive oxygen species (ROS) [61]. This method detects ROS in cell complete culture media, enriched with serum and glutamine, but the assay is sensitive to all reactive oxygen species, including $\mathrm{OH}$, $\mathrm{HOO}, \mathrm{NO}, \mathrm{O}_{2}$, ONOO $^{-}[61]$.

Besides that, the loss of metabolic activity in MSC at high SNP dosage can be explained by activation of p53 and by an enhanced binding of $\mathrm{NO}$ to different heme-containing enzymes, including cytochrome $\mathrm{C}$ oxidase, catalase, and cytochrome $\mathrm{P} 450$. This affects the respiratory chain in mitochondria [62], peroxide detoxification by peroxisomes, and the oxidative degradation of many different compounds. Furthermore, macrophages displayed signs of cell death at $115 \mu \mathrm{M} \mathrm{NO}$ [32], indicating that this concentration can cause toxic effects, which is in line with our results.

The GTPase Ras is activated by nitrosylation [63] and activation of Ras results in activation of the c-Raf-MEK1/2-ERK1/2 signalling pathway. The signal transduction of Ras to ERK $1 / 2$ is part of the NRF2mediated oxidative stress response pathway analysed in this study (Table 2) [64]. Immunoblot analyses revealed the phosphorylation
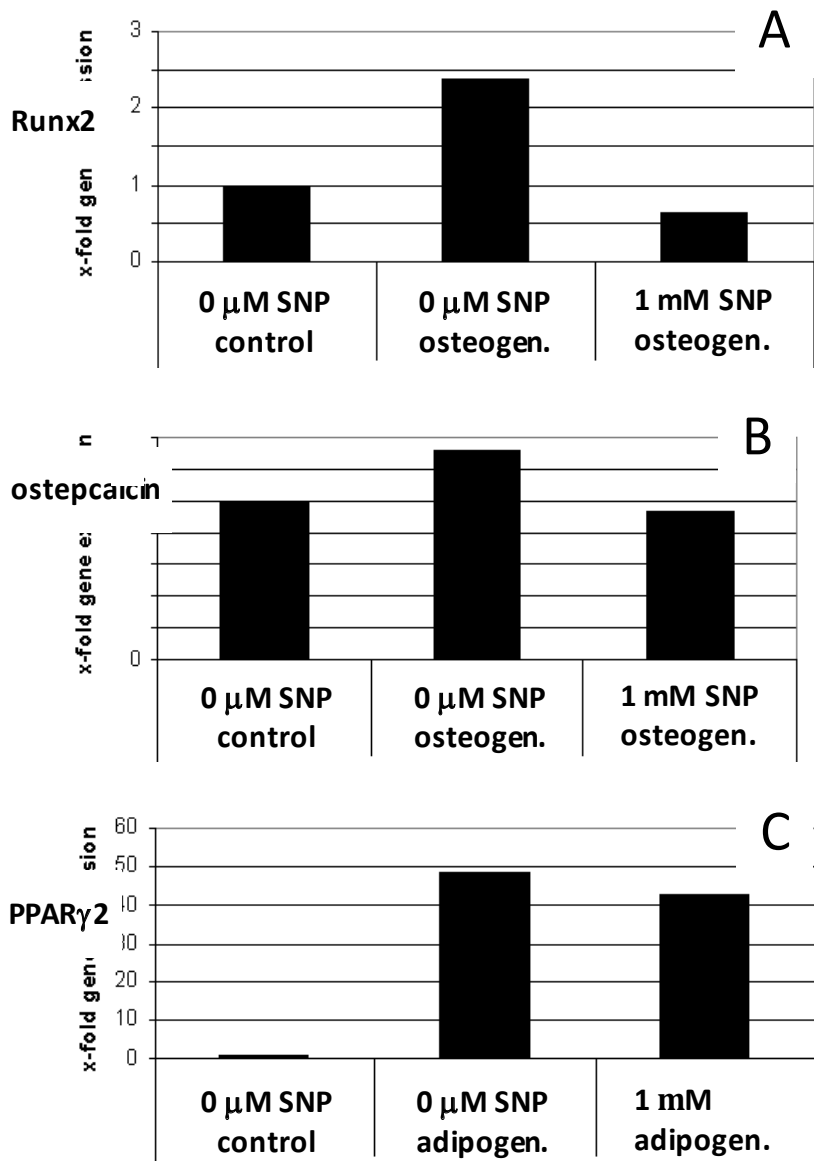

Figure 4: Effects of nitric oxide radicals on the differentiation of MSC

MSC were expanded and osteogenic or adipogenic differentiation was induced in the absence or presence of SNP. MSC in expansion media served as the control.

A Incubation of MSC in osteogenic induction medium for 7 days resulted in an increase in expression of the early osteogenic marker Runx2. Addition of SNP to osteogenic induction (daily change of medium containing $1 \mathrm{mM} \mathrm{SNP}$ ) blocked expression of Runx2.

B However, the expression of the late osteogenic marker osteocalcin was only slightly elevated and NO reduced this small increase to levels recorded in mock controls.

C Upon addition of adipogenic induction medium for 7 days to MSC, expression of the early adipogenic marker PPR $\gamma 2$ was drastically elevated, but a major NO effect was not recorded for adipogenesis (C). 
Citation: Felka T, Ulrich C, Rolauffs B, Mittag F, Kluba T, et al. (2014) Nitric Oxide Activates Signaling by c-Raf, MEK, p-JNK, p38 MAPK and p53 in Human Mesenchymal Stromal Cells and inhibits their Osteogenic Differentiation by Blocking Expression of Runx2. J Stem Cell Res Ther 4: 195. doi:10.4172/2157-7633.1000195

Page 7 of 9

of c-Raf as early as 15 minutes after addition of SNP to the MSC. The SNP concentration seems to have no influence on the kinetics of this process, since the pattern of phosphorylation of c-Raf was not different in MSC activated with $10 \mu \mathrm{M}$ or $1.5 \mathrm{mM}$ SNP (Figure 3). In contrast, a basic phosphorylation of MEK1/2 and ERK1/2 was observed prior to stimulation of the cells by SNP, and at almost all time points investigated (Figure 3). This may be attributed to the cell culture conditions employed. Therefore some activated MEK and ERK seem to be available at all times. But in contrast to ERK, MEK was transiently activated by $1.5 \mathrm{mM}$ by SNP, as were JNK and p38 MAP kinase. We therefore conclude that these two are the main MAP kinases involved in NO signaling downstream of Ras and Raf in MSC (Figure 5). Moreover, blocking JNK was shown to promote osteogenesis [65], supporting the working hypothesis that $\mathrm{NO}$ my influence the osteogenic differentiation of MSC via activation of JNK.

As discussed earlier, NO generates a complex pattern of cellular responses depending on targets and doses applied [27]. Recently a novel NO-dependent intracellular signalling pathway was described [66]. Here NO not only raises the cytoplasmic cGMP concentrations, but in addition generates a novel signalling molecule, the $8-\mathrm{NO}_{2}$ cGMP. A direct, chemical non-enzymatical nitrosylation of cGMP was suggested [66]. This pathway is important especially at higher concentrations of $\mathrm{NO}$, thus explaining in part the bi-phasic effects

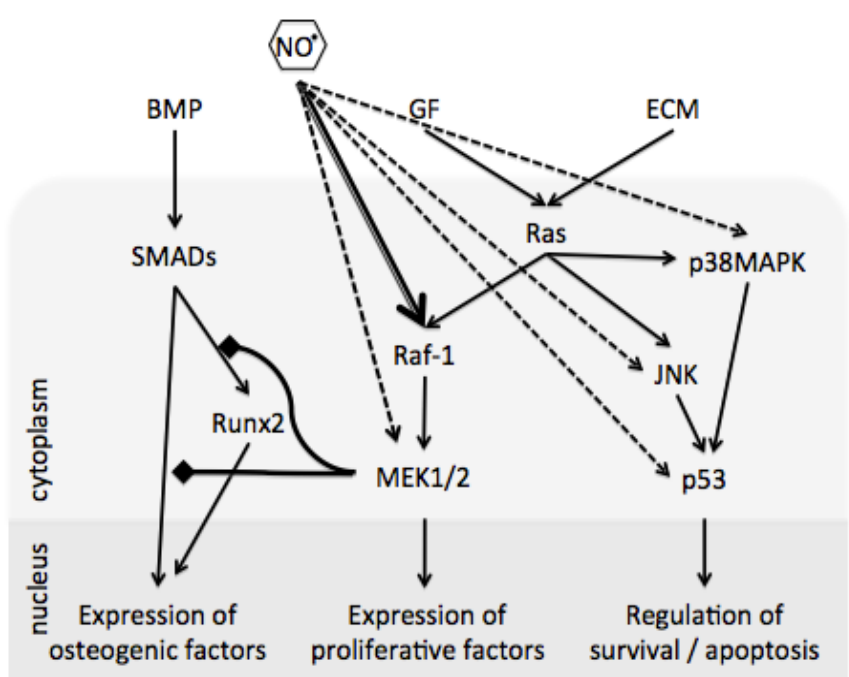

Figure 5: Proposed role of NO in the osteogenic, proliferative and apoptotic pathways in MSC.

The bone morphogenetic proteins (BMP) induce the phosphorylation of SMADs and facilitate their translocation in the nucleus. The SMADS contribute to expression of the key osteogenic factor Runx2 (left side of the panel). Growth factors (GF) such as fibroblast growth factor and the extracellular matrix (ECM) activate, among other pathways, the small GTPase Ras and the Ras-Rafpathway. Ras controls different signaling pathways, including different MAPkinases and p53 (right side of the panel). BMPs, GFs and the ECM regulate the gene expression required for osteogenic differentiation, proliferation and survival or apoptosis of MSC (thin solid arrows). Depending on the cell, MEK1/2 block the activation and nuclear translocation of SMADs (thick line with rombus), thus inhibiting expression of Runx2 (71). Nitric oxide radicals cause a transiently elevated phosphorylation of MEK1/2, p38MAPK, JNK, and p53 (thin dashed arrows) involved in proliferation, survival and apoptosis. Low NO activates c-Raf (thick arrow), which facilitates the activation of MEK1/2, and may thus interfere with SMAD- and Runx2-dependent regulation of expression in MSC. observed with NO on MSC. The 8- $\mathrm{NO}_{2}$-cGMP then generates cGMPmodified proteins by S-guanylation [66]. This post-translational modification was described with the redox sensor protein, Keap1. The cGMP-modified Keap1 cannot interact with NRF-2, thus providing an additional regulatory pathway for the NRF-2-mediated oxidative stress responses, complementing the p38MAPK- modulated NRF-2 responses discussed earlier.

Oxidative stress plays an important role in aseptic loosening of orthopaedic endoprostheses $[67,68]$ and high-output production of $\mathrm{NO}$ by $\mathrm{CD}^{+} 8^{+}$cells in the interface membrane was recorded $[69,70]$. We provide evidence that the elevated production of NO blocks the osteogenic differentiation of MSC by reducing the expression of Runx2 [54,71]. Blocking osteogenesis of MSC may allusively contribute to the formation of the characteristic interface membrane, which contains activated fibroblasts that resorb the bone matrix [72]. Moreover, elevated NO contributes to loss of bone mass and therefore seems to promote osteoporosis [73-75]. However, the regulation of Runx2 is complex and both activatory and inhibitory effects were observed, depending on the experimental set-up [71,76] (Figure 5). In contrast, low doses of $\mathrm{NO}$ may facilitate osteogenic differentiation or $\mathrm{NO}$ facilitated MSC-mediated tissue repair in vivo [77,78]. Low NO thus may be beneficial to patients suffering from osteoporosis or bone defects.

\section{Conclusions}

In summary, low dose NO does not reduce the viability or respiratory activity of MSC, nor activate the p38-, JNK- or p53-pathways, but activates c-Raf. This represents possibly the range of a rather beneficial NO dosage with regard to MSC proliferation or viability. In contrast, at higher SNP dosages, pathways associated with cell death and cancer is activated. In addition, the osteogenic differentiation of MSC is impaired by NO radicals, whereas adipogenesis is not affected. Therefore, at sites of tissue regeneration removal of pro-inflammatory and NO-producing cells or pharmacological control of NO production may increase the chances for efficient bone regeneration by MSC.

\section{Acknowledgements}

We thank Prof. K. E. Geckeler (GIST, Gwangju, Korea) and G. Zhou PhD for providing the water-soluble fulleren, Tanja Abruzzese and Stephanie Zug for excellent technical assistance, and Chaim Goziga for help in preparation of the artwork. This work was supported by the Netzwerk Regenerative Orthopädie (NRO) of the DGOOC, the German Ministry of Education and Research (BMBF grant 0313755), the DFG (grant Ai16/19-1), the Baden-Württemberg-Stiftung (grant Fi220052009), and in part by institutional sources.

\section{References}

1. Pittenger MF, Mackay AM, Beck SC, Jaiswal RK, Douglas R, et al. (1999) Multilineage potential of adult human mesenchymal stem cells. Science 284 (5411): 143-147. [Pubmed]

2. Kolf CM, Cho E, Tuan RS (2007) Mesenchymal stromal cells. Biology of adult mesenchymal stem cells: regulation of niche, self-renewal and differentiation. Arthritis Res Ther 9(1): 204.[Pubmed]

3. Chamberlain G, Fox J, Ashton B, Middleton J (2007) Concise review: mesenchymal stem cells: their phenotype, differentiation capacity, immunological features, and potential for homing. Stem Cells 25(11): 27392749. [Pubmed]

4. Le Blanc K, Frassoni F, Ball L, Locatelli F, Roelofs H, et al. (2008) Mesenchymal stem cells for treatment of steroid-resistant, severe, acute graft-versus-host disease: a phase II study. Lancet 371(9624): 1579-1586. [Pubmed]

5. Tian Y, Deng YB, Huang YJ, Wang Y (2008) Bone marrow-derived mesenchymal stem cells decrease acute graft-versus-host disease after allogeneic hematopoietic stem cells transplantation. Immunol Invest 37(1): 2942. [Pubmed] 
Citation: Felka T, Ulrich C, Rolauffs B, Mittag F, Kluba T, et al. (2014) Nitric Oxide Activates Signaling by c-Raf, MEK, p-JNK, p38 MAPK and p53 in Human Mesenchymal Stromal Cells and inhibits their Osteogenic Differentiation by Blocking Expression of Runx2. J Stem Cell Res Ther 4: 195. doi:10.4172/2157-7633.1000195

Page 8 of 9

6. Djouad F, Bouffi C, Ghannam S, Noël D, Jorgensen C (2009) Mesenchymal stem cells: innovative therapeutic tools for rheumatic diseases. Nat Rev Rheumatol 5(7): 392-399. [Pubmed]

7. Dominici M, Le Blanc K, Mueller I, Slaper-Cortenbach I, Marini F, et al. (2006). Minimal criteria for defining multipotentmesenchymal stromal cells. The International Society for Cellular Therapy position statement. Cytotherapy 8(4): 315-317. [Pubmed]

8. Tormin A, Li O, Brune JC, Walsh S, Schütz B, et al. (2011) CD146 expression on primary nonhematopoietic bone marrow stem cells is correlated with in situ localization. Blood 117(19): 5067-5077. [Pubmed]

9. Aicher WK, Bühring HJ, Hart M, Rolauffs B, Badke A, et al. (2011) Regeneration of cartilage and bone by defined subsets of mesenchymal stromal cellspotential and pitfalls. Adv Drug Deliv Rev 63(4-5): 342-351. [Pubmed]

10. Diduch DR, Jordan LC, Mierisch CM, Balian G (2000) Marrow stromal cells embedded in alginate for repair of osteochondral defects. Arthroscopy 16(6): 571-577. [Pubmed]

11. Quarto R, Mastrogiacomo M, Cancedda R, Kutepov SM, Mukhachev V, et al (2001) Repair of large bone defects with the use of autologous bone marrow stromal cells. N Engl J Med 344(5): 385-386. [Pubmed]

12. Horwitz EM, Prockop DJ, Gordon PL, Koo WW, Fitzpatrick LA, et al. (2001) Clinical responses to bone marrow transplantation in children with severe osteogenesisimperfecta. Blood 97(5): 1227-1231. [Pubmed]

13. Horwitz EM, Gordon PL, Koo WK, Marx JC, Neel MD, et al. (2002) Isolated allogeneic bone marrow-derived mesenchymal cells engraft and stimulate growth in children with osteogenesisimperfecta: Implications for cell therapy of bone. ProcNatlAcadSci U S A 99(13): 8932-8937. [Pubmed]

14. Wakitani S, Nawata M, Tensho K, Okabe T, Machida H, et al. (2007) Repair of articular cartilage defects in the patello-femoral joint with autologous bone marrow mesenchymal cell transplantation: three case reports involving nine defects in five knees. J Tissue EngRegen Med 1(1): 74-79. [Pubmed]

15. Wakitani S, Okabe T, Horibe S, Mitsuoka T, Saito M, et al. (2011) Safety of autologous bone marrow-derived mesenchymal stem cell transplantation for cartilage repair in 41 patients with 45 joints followed for up to 11 years and 5 months. J Tissue EngRegen Med 5(2): 146-150. [Pubmed]

16. Dezawa M1, Ishikawa H, Itokazu Y, Yoshihara T, Hoshino M, et al. (2005) Bone marrow stromal cells generate muscle cells and repair muscle degeneration. Science 309(5732): 314-317. [Pubmed]

17. Childs R, Chernoff A, Contentin N, Bahceci E, Schrump D, et al. (2000) Regression of Metastatic Renal-Cell Carcinoma after Nonmyeloablative Allogeneic Peripheral-Blood Stem-Cell Transplantation. N Engl J Med 343(11): 750-758. [Pubmed]

18. Au P, Tam J, Fukumura D, Jain RK (2008) Bone marrow-derived mesenchymal stem cells facilitate engineering of long-lasting functional vasculature. Blood 111(9): 4551-4558. [Pubmed]

19. Oskowitz A, McFerrin H, Gutschow M, Carter ML, Pochampally R (2011) Serum-deprived human multipotentmesenchymal stromal cells (MSCs) are highly angiogenic. Stem Cell Res 6(3): 215-225. [Pubmed]

20. Bogdan C (2001) Nitric oxide and the immune response. Nat Immunol 2(10): 907-916. [Pubmed]

21. Felka T, Schäfer R, Schewe B, Benz K, Aicher WK (2009) Hypoxia reduces the inhibitory effect of IL-1beta on chondrogenic differentiation of FCS-free expanded MSC. Osteoarthritis Cartilage 17(10): 1368-1376. [Pubmed]

22. Ghali O, Chauveau C, Hardouin P, Broux O, Devedjian JC (2010) TNF-alpha's effects on proliferation and apoptosis in human mesenchymal stem cells depend on RUNX2 expression. J Bone Miner Res 25(7): 1616-1626. [Pubmed]

23. McKee CM, Lowenstein CJ, Horton MR, Wu J, Bao C, et al. (1997) Hyaluronan fragments induce nitric-oxide synthase in murine macrophages through a nuclear factor kappaB-dependent mechanism. J BiolChem 272(12): 80138018. [Pubmed]

24. Bogdan C (2001) Nitric oxide and the regulation of gene expression. Trends Cell Biol 11(2): 66-75. [Pubmed]

25. Chin MPH (2010) Prediction of nitric oxide concentrations during inflammation and carcinogenesis. Massachusetts Inst Technology, Boston, MA

26. Moilanen E, Moilanen T, Knowles R, Charles I, Kadoya Y, et al. (1997) Nitric oxide synthase is expressed in human macrophages during foreign body inflammation. Am J Pathol 150(3): 881-887.[Pubmed]
27. Hill BG, Dranka BP, Bailey SM, Lancaster JR Jr, Darley-Usmar VM (2010) What part of NO don't you understand? Some answers to the cardinal questions in nitric oxide biology. J BiolChem 285(26): 19699-19704. [Pubmed]

28. Rizk M, Witte MB, Barbul A (2004) Nitric oxide and wound healing. World J Surg 28(3): 301-306. [Pubmed]

29. Ren G, Zhang L, Zhao X, Xu G, Zhang Y, et al. (2008) Mesenchymal stem cellmediated immunosuppression occurs via concerted action of chemokines and nitric oxide. Cell Stem Cell 2(2): 141-150. [Pubmed]

30. Green SJ, Meltzer MS, Hibbs JBJr, Nacy CA (1990) Activated macrophages destroy intracellular Leishmania major amastigotes by an L-arginine-dependent killing mechanism. J Immunology 144(1): 278-283. [Pubmed]

31. Albakri QA, Stuehr DJ (1996) Intracellular assembly of inducible NO synthase is limited by nitric oxide-mediated changes in heme insertion and availability. $J$ BiolChem 271(10): 5414-5421. [Pubmed]

32. Albina JE, Cui S, Mateo RB, Reichner JS (1993) Nitric oxide-mediated apoptosis in murine peritoneal macrophages. J Immunol 150(11): 5080-5085. [Pubmed]

33. Wood J, Garthwaite J (1994) Models of the diffusional spread of nitric oxide: implications for neural nitric oxide signalling and its pharmacological properties. Neuropharmacology 33(11): 1235-1244. [Pubmed]

34. Hanafy KA, Krumenacker JS, Murad F (2001) NO, nitrotyrosine, and cyclic GMP in signal transduction. Med SciMonit 7(4): 801-819. [Pubmed]

35. Hall CN, Garthwaite J (2009) What is the real physiological NO concentration in vivo? Nitric Oxide 21(2): 92-103. [Pubmed]

36. Wink DA, Vodovotz Y, Laval J, Laval F, Dewhirst MW, et al. (1998) The multifaceted roles of nitric oxide in cancer. Carcinogenesis 19(5): 711-721. [Pubmed]

37. Cheng A, Chan SL, Milhavet O, Wang S, Mattson MP (2001) p38 MAP kinase mediates nitric oxide-induced apoptosis of neural progenitor cells. J BiolChem 276(46): 43320-43327. [Pubmed]

38. McLaughlin LM, Demple B (2005) Nitric oxide-induced apoptosis in lymphoblastoid and fibroblast cells dependent on the phosphorylation and activation of p53. Cancer Res 65(14): 6097-6104. [Pubmed]

39. Zeini M, Través PG, López-Fontal R, Pantoja C, Matheu A, et al. (2006) Specific contribution of p19(ARF) to nitric oxide-dependent apoptosis. Immunol 177(5): 3327-3336. [Pubmed]

40. Madhusoodanan KS, Murad F (2007) NO-cGMP signaling and regenerative medicine involving stem cells. Neurochem Res 32(4-5): 681-694. [Pubmed]

41. Lee DH, Pfeifer GP (2007) Mutagenesis induced by the nitric oxide donor sodium nitroprusside in mouse cells. Mutagenesis 22(1): 63-67. [Pubmed]

42. Lepic E, Burger D, Lu X, Song W, Feng Q (2006) Lack of endothelial nitric oxide synthase decreases cardiomyocyte proliferation and delays cardiac maturation. Am J Physiol Cell Physiol 291(6): C1240-C1246.[Pubmed]

43. Kristof AS, Goldberg P, Laubach V, Hussain SN (1998) Role of inducible nitric oxide synthase in endotoxin-induced acute lung injury. Am J RespirCrit Care Med 158(6): 1883-1889. [Pubmed]

44. Chatterjee PK, Patel NS, Sivarajah A, Kvale EO, Dugo L, et al. (2003) GW274150, a potent and highly selective inhibitor of iNOS, reduces experimental renal ischemia/reperfusion injury. Kidney Int 63(3): 853-865. [Pubmed]

45. Laroux FS, Lefer DJ, Kawachi S, Scalia R, Cockrell AS, et al. (2000) Role of nitric oxide in the regulation of acute and chronic inflammation. Antioxid Redox Signal 2(3): 391-396.[Pubmed]

46. Felka T, Schäfer R, De Zwart P, Aicher WK (2010) Animal serum-free expansion and differentiation of human mesenchymal stromal cells. Cytotherapy 12(2): 143-153. [Pubmed]

47. Pilz GA, Braun J, Ulrich C, Felka T, Warstat K, et al. (2011) Human mesenchymal stromal cells express CD14 cross-reactive epitopes. CytometryA 79(8): 635-645. [Pubmed]

48. Rapoport RM, Draznin MB, Murad F (1983) Endothelium-dependent relaxation in rat aorta may be mediated through cyclic GMP-dependent protein phosphorylation. Nature 306(5939): 174-176. [Pubmed]

49. Sasaki Y, Seki J, Giddings JC, Yamamoto J (1996) Effects of NO-donors on 
Citation: Felka T, Ulrich C, Rolauffs B, Mittag F, Kluba T, et al. (2014) Nitric Oxide Activates Signaling by c-Raf, MEK, p-JNK, p38 MAPK and p53 in Human Mesenchymal Stromal Cells and inhibits their Osteogenic Differentiation by Blocking Expression of Runx2. J Stem Cell Res Ther 4: 195. doi:10.4172/2157-7633.1000195

Page 9 of 9

thrombus formation and microcirculation in cerebral vessels of the rat. Thromb Haemost 76(1): 111-117. [Pubmed]

50. Zhou G, Harruna II, Zhou WL, Aicher WK, Geckeler KE (2007) Nanostructured thermosensitive polymers with radical scavenging ability. Chemistry 13(2): 569 573. [Pubmed]

51. Rasmussen R, Morrison T, Herrmann M, Wittwer C (1998) Quantitative PCR by continuous fluorescence monitoring of a double strand dna specific binding dye. Biochemica 2: 8-11.

52. Jaiswal AK (2004) Nrf2 signaling in coordinated activation of antioxidant gene expression. Free RadicBiol Med 36(10): 1199-1207. [Pubmed]

53. Lai LP, Mitchell J (2009) Parathyroid hormone inhibits phosphorylation of mitogen-activated protein kinase (MAPK) ERK1/2 through inhibition of c-Raf and activation of MKP-1 in osteoblastic cells. Cell Biochemistry and Function 27(5): 269-275. [Pubmed]

54. Schroeder TM, Jensen ED, Westendorf JJ (2005) Runx2: a master organizer of gene transcription in developing and maturing osteoblasts. Birth Defects Res C Embryo Today 75(3): 213-225. [Pubmed]

55. Denninger JW, Marletta MA (1999) Guanylatecyclase and the .NO/cGMP signaling pathway. BiochimBiophysActa 1411(2-3): 334-350. [Pubmed]

56. Fraser M, Chan SL, Chan SS, Fiscus RR, Tsang BK (2006) Regulation of p53 and suppression of apoptosis by the soluble guanylylcyclase/cGMP pathway in human ovarian cancer cells. Oncogene 25(15): 2203-2212. [Pubmed]

57. Fu M, Wang C, Li Z, Sakamaki T, Pestell RG (2004) Minireview: Cyclin D1: normal and abnormal functions. Endocrinology 145(12): 5439-5447. [Pubmed]

58. Chang F, Steelman LS, Shelton JG, Lee JT, Navolanic PM, et al. (2003) Regulation of cell cycle progression and apoptosis by the Ras/Raf/MEK/ERK pathway (Review). Int J Oncol 22(3): 469-480. [Pubmed]

59. Vesey CJ, Stringer M, Cole PV (1990) Decay of nitroprusside. I: In vitro. Br J Anaesth 64(6): 696-703. [Pubmed]

60. Ridnour LA, Sim JE, Hayward MA, Wink DA, Martin SM, et al. (2000) A spectrophotometric method for the direct detection and quantitation of nitric oxide, nitrite, and nitrate in cell culture media. Anal Biochem 281(2): 223-229. [Pubmed]

61. Uy B, McGlashan SR, Shaikh SB (2011) Measurement of reactive oxygen species in the culture media using AcridanLumigen PS-3 assay. J Biomol Tech 22(3): 95-107. [Pubmed]

62. Feelisch M (2007) Nitrated cyclic GMP as a new cellular signal. Nat Chem Bio 3(11): 687-688. [Pubmed].

63. Lander HM, Ogiste JS, Pearce SF, Levi R, Novogrodsky A (1995) Nitric oxidestimulated guanine nucleotide exchange on p21ras. J Biol Chem 270(13): 7017-7020. [Pubmed]

64. Schindeler A, Little DG (2006) Ras-MAPK signaling in osteogenic differentiation friend or foe? J Bone Miner Res 21(9): 1331-1338. [Pubmed]

65. Sullivan K, El-Hoss J, Little DG, Schindeler A (2011) JNK inhibitors increase osteogenesis in Nf1-deficient cells. Bone 49(6): 1311-1316. [Pubmed]

66. Sawa T, Zaki MH, Okamoto T, Akuta T, Tokutomi Y, et al. (2007) Protein S-guanylation by the biological signal 8-nitroguanosine 3',5'-cyclic monophosphate. Nat Chem Biol 3(11): 727-735. [Pubmed]

67. Wozniak W, Markuszewski J, Wierusz-Kozlowska M, Wysocki H (2004) Neutrophils are active in total joint implant loosening. Acta Orthop Scand 75(5): 549-553. [Pubmed]
68. Kinov $P$, Leithner A, Radl R, Bodo K, Khoschsorur GA, et al. (2006) Role of free radicals in aseptic loosening of hip arthroplasty. J Orthop Res 24(1): 5562. [Pubmed]

69. Hukkanen M, Corbett SA, Batten J, Konttinen YT, McCarthy ID, et al. (1997) Aseptic loosening of total hip replacement. Macrophage expression of inducible nitric oxide synthase and cyclo-oxygenase-2, together with peroxynitrite formation, as a possible mechanism for early prosthesis failure. J Bone Joint Surg $\mathrm{Br}$ 79(3): 467-474. [Pubmed]

70. El-Warrak AO, Olmstead M, Schneider R, Meinel L, Bettschart-Wolfisberger $R$, et al. (2004) An experimental animal model of aseptic loosening of hip prostheses in sheep to study early biochemical changes at the interface membrane. BMC Musculoskelet Disord 5: 7. [Pubmed]

71. Zhao Y, Song T, Wang W, Wang J, He J, et al. (2012) P38 and ERK1/2 MAPK act in opposition to regulate BMP9-induced osteogenic differentiation of mesenchymal progenitor cells. PLoS One 7(8): e43383. [Pubmed]

72. Pap T, Claus A, Ohtsu S, Hummel KM, Schwartz P, et al. (2003) Osteoclastindependent bone resorption by fibroblast-like cells. Arthritis Res Ther 5(3): R163-R173. [Pubmed]

73. Hao YJ, Tang Y, Chen FB, Pei FX (2005) Different doses of nitric oxide donor prevent osteoporosis in ovariectomized rats. Clin Orthop Relat Res (435): 226 231. [Pubmed]

74. Wimalawansa SJ (2008) Nitric oxide: novel therapy for osteoporosis. Expert Opin Pharmacother 9(17): 3025-3044. [Pubmed]

75. Armour KE, Van'T Hof RJ, Grabowski PS, Reid DM, Ralston SH (1999) Evidence for a pathogenic role of nitric oxide in inflammation-induced osteoporosis. J Bone Miner Res 14(12): 2137-2142. [Pubmed]

76. Watanabe H, de Caestecker MP, Yamada Y (2001) Transcriptional Cross-talk between Smad, ERK1/2, and p38 Mitogen-activated Protein Kinase Pathways Regulates Transforming Growth Factor- $\hat{I}^{2}$-induced Aggrecan Gene Expression in Chondrogenic ATDC5 Cells. J Biol Chem 276(17): 14466-14473. [Pubmed]

77. Ocarino NM, Boeloni JN, Goes AM, Silva JF, Marubayashi U, et al. (2008) Osteogenic differentiation of mesenchymal stem cells from osteopenic rats subjected to physical activity with and without nitric oxide synthase inhibition Nitric Oxide 19(4): 320-325. [Pubmed]

78. Ali G, Mohsin S, Khan M, Nasir GA, Shams S, et al. (2012) Nitric oxide augments mesenchymal stem cell ability to repair liver fibrosis. J Transl Med 10: 75.[Pubmed] 